\title{
Commentary: Aortic annuloplasty: One size does not fit all
}

\author{
Maral Ouzounian, $\mathrm{MD}, \mathrm{PhD},{ }^{\mathrm{a}}$ \\ Michael W. A. Chu, MD, MEd, ${ }^{\text {b }}$ \\ Mark D. Peterson, MD, $\mathrm{PhD},{ }^{\mathrm{a}}$ and \\ Ismail El-Hamamsy, $\mathrm{MD}, \mathrm{PhD},{ }^{\mathrm{c}}$ on behalf of the \\ Canadian Thoracic Aortic Collaborative (CTAC)
}

Every component of the aortic root must be evaluated and restored to structural and functional competence for a durable repair. Failure to address the functional aortic annulus during aortic valve repair or root reconstruction has led to early failures, and several techniques have been developed to correct and prevent annular dilatation. Available data are marred by small numbers, alterations in technique over time, retrospective and incomplete data, and a lack of a comparator group. Failure to address other components of root morphology, particularly residual cusp prolapse or inadequate coaptation height, also lead to early failure, making it difficult to isolate the effect of annuloplasty on repair durability.

\section{ARE ALL ANNULOPLASTY TECHNIQUES EQUALLY EFFECTIVE?}

The accompanying review paper by Professor Schafers' group nicely summarizes the concepts behind aortic valve annuloplasty. ${ }^{1}$ The techniques include (1) subcommissural annular plication; (2) suture annuloplasty; (3) internal rings; (4) external rings or bands; and (5) reimplantation of the aortic valve. Of note, the first 3 options do not require

\footnotetext{
From the aivision of Cardiovascular Surgery, University of Toronto, Toronto, Ontario, Canada; ${ }^{\mathrm{b}}$ Division of Cardiac Surgery, Western University, London, Ontario, Canada; and ${ }^{c}$ Department of Cardiovascular Surgery, Mount Sinai Hospital and Icahn School of Medicine at Mount Sinai, New York, NY.

Disclosures: The authors reported no conflicts of interest.

The Journal policy requires editors and reviewers to disclose conflicts of interest and to decline handling or reviewing manuscripts for which they may have a conflict of interest. The editors and reviewers of this article have no conflicts of interest.

Received for publication Jan 13, 2021; revisions received Jan 13, 2021; accepted for publication Jan 13, 2021; available ahead of print Jan 20, 2021.

Address for reprints: Maral Ouzounian, MD, PhD, Division of Cardiovascular Surgery, University of Toronto, Toronto, Ontario, Canada (E-mail: maral. ouzounian@uhn.ca).

JTCVS Techniques 2021;7:103-4

2666-2507

Copyright (C) 2021 The Authors. Published by Elsevier Inc. on behalf of The American Association for Thoracic Surgery. This is an open access article under the CC BY-NCND license (http://creativecommons.org/licenses/by-nc-nd/4.0/).

https://doi.org/10.1016/j.xjtc.2021.01.016
}

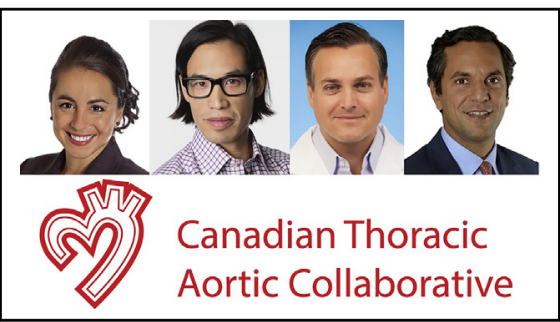

Photo of the authors, members of the Canadian Thoracic Aortic Collaborative.

\section{CENTRAL MESSAGE \\ A variety of annuloplasty tech- niques exist that may be used to correct aortic annular dilatation and support aortic valve and root reconstruction.}

deep circumferential dissection externally down to the basal ring.

Subcommissural annuloplasty alone is not effective in treating gross annular dilatation ${ }^{2,3}$ and has been largely abandoned but may be useful in limited instances such as treating a commissural leak. Suture annuloplasty has been reported to improve valve competence in remodeling or isolated valve repair in centers of expertise ${ }^{4}$; however, reproducibility and durability are unclear. It may be useful when external dissection is challenging, such as redo operations or bicuspid valves with a large distance between the basal ring and the ventriculoaortic junction. An internal rigid ring has been proposed as easier to implant; however, only early outcomes on a limited number of patients have been reported. ${ }^{5}$ We are concerned that forcing a massively dilated annulus down to a rigid ring without external support may lead to dehiscence of the ring. Furthermore, interaction of the valve cusps with the internal ring may damage the cusps. Finally, while most regurgitant bicuspid valves are Sievers I, the internal ring is preshaped at $180^{\circ}$.

The reimplantation technique uses a series of pledgeted sutures internally and the base of the graft externally as the supporting annuloplasty. It has been considered to provide the best annular stabilization and provides excellent late results into the third decade. ${ }^{6-9}$ Concerns raised about failure of root remodeling in patients with annuloaortic ectasia may be obviated by the addition of an external annuloplasty with a circumferential ring or Dacron band. ${ }^{10,11}$

In summary, several annuloplasty techniques exist to correct annular dilatation and improve the surface of 
coaptation of the aortic valve, and these should be tailored to each individual. We suggest that the reimplantation technique should be the standard against which other techniques are compared. Systematic reporting of late results on patients followed prospectively with imaging is crucial to accurately determine the role of these techniques in our armamentarium. Stabilization of the aortic annulus is critical but is only one ingredient in a complex recipe leading to durable late results in patients undergoing reconstructive aortic valve surgery.

\section{References}

1. Federspiel J, Ehrlich T, Abeln K, Schafers H-J. Aortic annuloplasty: subcommissural, intra-annular suture techniques, external and internal rings. J Thorac Cardiovasc Surg Tech. 2021;7:98-102.

2. Aicher D, Kunihara T, Abou Issa O, Brittner B, Graber S, Schafers HJ. Valve configuration determines long-term results after repair of the bicuspid aortic valve. Circulation. 2011;123:178-85.

3. de Kerchove L, Mastrobuoni S, Boodhwani M, Astarci P, Rubay J, Poncelet A, et al. The role of annular dimension and annuloplasty in tricuspid aortic valve repair. Eur J Cardiothorac Surg. 2016;49:428-37; discussion 437-8.
4. Aicher D, Schneider U, Schmied W, Kunihara T, Tochii M, Schafers HJ. Early results with annular support in reconstruction of the bicuspid aortic valve. $J$ Thorac Cardiovasc Surg. 2013;145:S30-4.

5. Rankin JS, Mazzitelli D, Fischlein T, Choi YH, Pirk J, Pfeiffer S, et al. Geometric ring annuloplasty for aortic valve repair during aortic aneurysm surgery: twoyear clinical trial results. Innovations (Phila). 2018;13:248-53.

6. David TE, David CM, Ouzounian M, Feindel CM, Lafreniere-Roula M. A progress report on reimplantation of the aortic valve. J Thorac Cardiovasc Surg. September 4, 2020 [Epub ahead of print].

7. Mastrobuoni S, de Kerchove L, Navarra E, Watremez C, Vancraeynest D, Rubay J, et al. Long-term experience with valve-sparing reimplantation technique for the treatment of aortic aneurysm and aortic regurgitation. J Thorac Cardiovasc Surg. 2019;158:14-23.

8. Nawaytou O, Mastrobuoni S, de Kerchove L, Baert J, Boodhwani M, El Khoury G. Deep circumferential annuloplasty as an adjunct to repair regurgitant bicuspid aortic valves with a dilated annulus. J Thorac Cardiovasc Surg. 2018; 156:590-7.

9. Valdis M, Thain A, Jones PM, Chan I, Chu MWA. Multimodal imaging of aortic annulus and root geometry after valve sparing root reconstruction. Ann Cardiothorac Surg. 2019;8:362-71.

10. Lansac E, Di Centa I, Sleilaty G, Lejeune S, Khelil N, Berrebi A, et al. Long-term results of external aortic ring annuloplasty for aortic valve repair. Eur J Cardiothorac Surg. 2016;50:350-60.

11. Lenoir M, Maesen B, Stevens LM, Cartier R, Demers P, Poirier N, et al. Reimplantation versus remodelling with ring annuloplasty: comparison of mid-term outcomes after valve-sparing aortic root replacement. Eur J Cardiothorac Surg. 2018;54:48-54. 